\title{
Papyrus and Papyrus-like paper sheets, their quality in relation to anatomical features
}

\author{
Nahed M. Waly \\ Herbarium, Botany Department \\ Faculty of Science, Giza 12613, Egypt. \\ Waly, N. M. 2001. Papyrus and Papyrus - like paper sheets, their quality in relation to anatomical features. \\ Taeckholmia 21(1): 135-141. \\ Papyrus and papyrus-like paper sheet were fabricated from the culms of sedges, rushes, and grasses and the leaf \\ blades of banana The characters and quality of the manufactured paper sheets are discussed in relation to the \\ cellular structure of the relevant plant organs used for the production of paper sheets. The best and good qualities \\ of paper sheets are those manufactured from culms consisting of high amounts of cellulose element including \\ parenchyma aerenchyma. The moderate and lower qualities of paper sheets comprise, in addition to cellulosic \\ elements, higher amounts of lignified elements including fibre
}

Key words: Cellular elements, papyrus and papyrus-like paper sheets quality

\section{Introduction}

The writing material made of papyrus plant (Cyperus papyrus L.) or similar species provided the most important surface for recording wide information of ancient Egypt. This constitutes the "Papyrus" manuscripts or sheets, which are of considerable value as national heritage (Lucas: 1962). Such manuscripts are scattered all over Egypt in the libraries of monasteries, private collections as well as Egyptian museums. They deserve special studies, which are related to its origin, the mode of its manufacture or even the utilized plant material.

According to El Hadidi, (1982:109) the reed matting remains recovered in Hierakonpolis (3800-2770 BC) do not constitute mats in the real sense. The culms of the reed (complete or longitudinally halved) were cross-laid, neither woven nor tied and seemed suggestive of the pattern followed later in the paper industry from the culms of two or more Cyperus species (eventually Cyperus alopecuroides and C. Papyrus)

El Hadidi (op.cit.) argued that the paper” scrolls” of Ancient Egypt were made of the pith of at least one species of Cyperus and that cheaper and less valuable papyrus sheets or scrolls were manufactured from the culms of Cyperus alopecuroides. The latter was also the source for the manufacture of mats, basketry, etc. (cf. Täckholm \& Drar, 1950:119-127).

The present account aims to apply the traditional ancient Egyptian technique (cf. Ragab, 1988) for the production of papyrus-like paper sheets from materials belonging to different plants including sedges, grasses and rushes. The quality of the produced sheets will be evaluated in the light of the anatomical features, viz. the cellular constituents of the materials used. 


\section{Material and Methods}

\section{1-Sheet fabrication}

For comparing the characters of real papyrus and papyrus-like sheets, we prepared such sheets from the culms and leaves of the following species:

Sedges: culms of Cyperus papyrus, C. alopecuroides, C. articulatus, and C. alternifolius. Rushes: culms of Juncus rigidus and J. acutus

Grasses: culms of Zea mays, Saccharum officinarum, and Phragmites australis.

Banana: leaves of Musa nana.

The principal method followed is that described by Basile and Dá Natale (1996). The manufactured paper sheets varied in colour between bright yellow to light brown and are either thin (up to $0.50 \mathrm{~mm}$ thick) or thick $(0.50-0.75 \mathrm{~mm}$ thick)

\section{2-Anatomical investigations}

Cross-sections in the culms or leaves, 30-50 $\mu \mathrm{m}$ thick for examination by light microscope were stained using safranin and light green. Stained sections were dehydrated in alcohol-xylol series, cleared in clove oil and mounted in Canada Balsam.

\section{Results}

Table (1) gives the characters and quality of the manufactured paper sheets from the organs belonging to the investigated species.

Table (1): Quality and characters of the produced paper sheets /plant used

\begin{tabular}{|l|l|l|}
\hline Species & Quality & Characters \\
\hline Cyperus papyrus (culm) & Best & Thin, flexible, smooth, strong, opaque, compact \\
\hline $\begin{array}{l}\text { Cyperus alopecuroides (culm) } \\
\text { Cyperus articulatus (culm) }\end{array}$ & Good & Less flexible, smooth, strong translucent, less \\
Juncus rigidus (culm) & Moderate & Thin brittle, rough, translucent, less compact \\
Musa nana (Leaf blade) & Moderate & \\
\hline $\begin{array}{l}\text { Phragmites australis (culm) } \\
\text { Zea mays (culm) }\end{array}$ & Low & \\
Saccharum officinarum (culm) & Low & Thick, brittle, rough, incompact \\
Cyperus alternifolius (culm) & Low & \\
Juncus acutus (culm) & Low & \\
\hline
\end{tabular}

It will be noticed that the best quality of paper is that from the culm of Cyperus papyrus which is thin (up to $0.50 \mathrm{~mm}$ thick), flexible, smooth, strong, and more compact.

The good quality paper was produced from culms of the sedges, Cyperus alopecuroides, and C. articulatus. The sheets are however thicker (0.5 mm thick), less flexible, smooth, strong and less compact. 
The moderate quality paper was produced from the leaves of banana (Musa nana) and the culms of tall rush (Juncus rigidus). The sheets are more or less thick (0.5$0.75 \mathrm{~mm}$ thick), brittle, rough, and compact.

The low quality paper is thick ( $0.75 \mathrm{~mm}$ thick), brittle, rough and incompact. It was produced from the culms of the grasses: Zea mays, Saccharum officinarum, Phragmites australis; as well as the culms of the bitter rush Juncus acutus and Cyperus alternifolius.

Table (2) summarizes the main anatomical features of the plant organs used for the production or manufacture of paper sheets. The best and good quality of paper sheets (table 2), requires the availability of wide ground tissue which consists mainly of parenchyma and preferably aerenchyma, which is a special type of parenchyma with wide intercellular spaces. This ground tissue is available in the culms of Cyperus papyrus, $C$. alopecuroides and $C$. articulatus where the paper sheet is only made from the pulp material and where no other constituents of the culm (boundary tissue, with fiber patches, etc.) are involved in the manufacture of paper sheets.

Table (2): Anatomical features of the organs used for preparation of paper sheets

\begin{tabular}{|c|c|c|c|c|c|}
\hline Species & Quality & \multicolumn{2}{|c|}{ Subepidermal fiber patches (in T.S.) } & $\begin{array}{l}\text { Fiber wall } \\
\text { thickness }\end{array}$ & Organ/Ground tissue \\
\hline Cyperus papyrus & best & round shaped & \multirow{3}{*}{$\begin{array}{l}\text { Surrounding V.B. } \\
\text { forming a caps above } \\
\text { and below bundle }\end{array}$} & $1 / 2$ lumen & \multirow{3}{*}{$\begin{array}{l}\text { Cculm/ wide consisted } \\
\text { of three armed } \\
\text { aerenchyma; and V.B. } \\
\text { surrounded with } \\
\text { parenchyma sheath }\end{array}$} \\
\hline $\begin{array}{l}\text { Cyperus } \\
\text { alopecuroide }\end{array}$ & good & oval shaped & & 2/3 lumen & \\
\hline Cyperus articulatus & good & absent & & 2/3 lumen & \\
\hline Juncus rigidus & moderate & triangular form & $\begin{array}{l}\text { Caps above and below } \\
\text { V.B. extending into a } \\
\text { long tail }\end{array}$ & $2 / 3$ lumen & $\begin{array}{l}\text { culm/ parenchyma } \\
\text { with air cavities }\end{array}$ \\
\hline Musa nana & moderate & round shaped & $\begin{array}{l}\text { upper and lower } \\
\text { separated smaller caps }\end{array}$ & 1/4 lumen & $\begin{array}{l}\text { Leaf/stellate } \\
\text { parenchyma }\end{array}$ \\
\hline Phragmites australis & low & $\begin{array}{l}\text { continuous } \\
\text { ring }\end{array}$ & $\begin{array}{l}\text { continuous, around } \\
\text { V.B. }\end{array}$ & $1 / 2$ lumen & culm/ parenchyma cells \\
\hline Zea mays & low & $\begin{array}{l}\text { elongated } \\
\text { patches }\end{array}$ & $\begin{array}{l}\text { large caps below and } \\
\text { above V.B. }\end{array}$ & 1/4 lumen & culm/ parenchyma cells \\
\hline $\begin{array}{l}\text { Saccharum } \\
\text { officimarum }\end{array}$ & low & absent & $\begin{array}{l}\text { surrounding V.B. with } \\
\text { larger lower cap }\end{array}$ & 1/2 lumen & culm/ parenchyma cells \\
\hline Cyperus alternifolius & low & $\begin{array}{l}\text { continuous } \\
\text { ring }\end{array}$ & $\begin{array}{l}\text { surrounding V.B. with } \\
\text { larger lower cap }\end{array}$ & $1 / 2$ lumen & $\begin{array}{l}\text { culm/ compact } \\
\text { parenchyma cells }\end{array}$ \\
\hline Juncus acutus & low & triangular form & $\begin{array}{l}\text { caps above and below } \\
\text { V.B. extending into a } \\
\text { long tail below }\end{array}$ & 3/4 lumen & $\begin{array}{l}\text { culm/ parenchyma } \\
\text { with small air cavities }\end{array}$ \\
\hline
\end{tabular}

The moderate quality paper involves the contribution of other constituents of the culm (fibrous tissues, etc.). This is the case of the paper sheets made of the Banana leaf blades (Musa nana) and the culm of the tall rush (Juncus rigidus). Here, other cellular elements including the epidermis, subepidermal fiber patches and the peripheral vascular bundles are the constituents of the manufactured paper sheets.

The low quality paper is manufactured from the ground tissue of the culms of the grasses: Zea mays, Phragmites australis, and Saccharum officinarum and the bitter rush Juncus acutus. Here the fibro-vascular systems of the culm as well as the epidermal and subepidermal fiber patches are the main constituents of the manufactured paper sheets. 


\section{Discussion}

The present investigation shows clearly a close relation between the quality of the paper and the cellular elements of the organs used in manufacturing the paper sheets. It is obvious that the paper sheets of the best or good quality are made of plant material consisting mainly of cellulosic tissues, (parenchyma, and aerenchyma). Here the pulp of the culm in Cyperus species (C. papyrus, C. alopecuroides, and C. articulatus) is the main constituent of the manufactured paper sheets. The ground tissue (pulp) comprises in addition to the aerenchyma, vascular bundles, each with a characteristic outer parenchyma sheath, which gives the paper its flexible and compact characters.

The compactness of the paper seems also to be related to the presence of the three-armed aerenchyma in the ground tissue (Fig. 1:a,b \& c). According to Nicholson \& Show (2000:233), recent experiments in paper manufacture from papyrus culms have all found that pressing the layers together was enough to ensure adhesion. Ragab (1980 a, 1980 b: 151-60) proposed that physical bonding is the main reason for the lamination and compactness of the horizontal and vertical layers of the papyrus paper. The pith of the papyrus stem is made up of ground tissue consisting of the three-armed aerenchyma cells with air spaces between them. When the two layers are pressed together during manufacture, the air is expelled, and the parenchyma cells are forced together, occupying the previous air spaces. They interlock in what Ragab describes as a dovetail effect; is the reason for the great compactness of the manufactured paper sheets.

The flexibility of the manufactured paper sheet can be related to the fiber wall thickness and of the amount of fiber cells as well as the parenchyma sheath surrounding the vascular bundles. In Cyperus papyrus, the manufactured sheets are the most flexible with smooth texture, which is due to thinner fiber cell walls (1/2 lumen) and the presence of outer parenchymatous layer surrounding the vascular bundle sheath (Metcalfe, 1971). In both Cyperus articulatus and C. alopecuroides, which produce good quality of rather smooth paper; the walls of the fiber cells are not exceeding 2/3 of the cell lumen.

In moderate quality paper sheets (brittle, rough and less compact) which is produced from Banana leaf blade or tall rush culm; the cellular elements comprise stellate parenchyma with narrower air spaces or normal parenchyma with air cavities in tall rush (Fig. 2a); as well as moderate amounts of fiber patches (or caps) which are located above and below the vascular bundles. The wall of the fiber cell is $1 / 2-2 / 3$ the lumen.

The low quality paper sheets (brittle, thick, rough and incompact) are produced from the culms of the grasses, Zea mays, Phragmites australis, Saccharum officinarum, and Juncus acutus. The ground tissue in these plants consists mainly of normal parenchyma cells with narrow air spaces (Fig. 2 b \& c) as well as large fiber patches which are located either above or below vascular bundles. The walls of fiber cells are apparently thick (1/2 -3/4 lumen). 


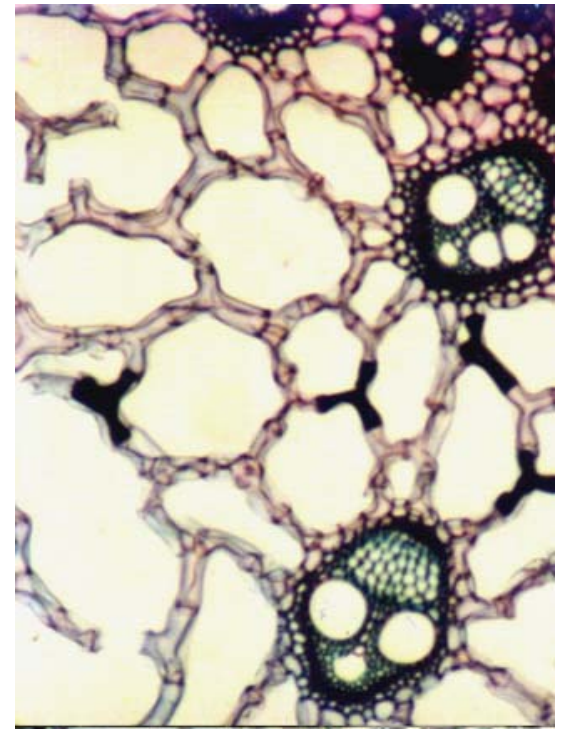

$\mathbf{a}$

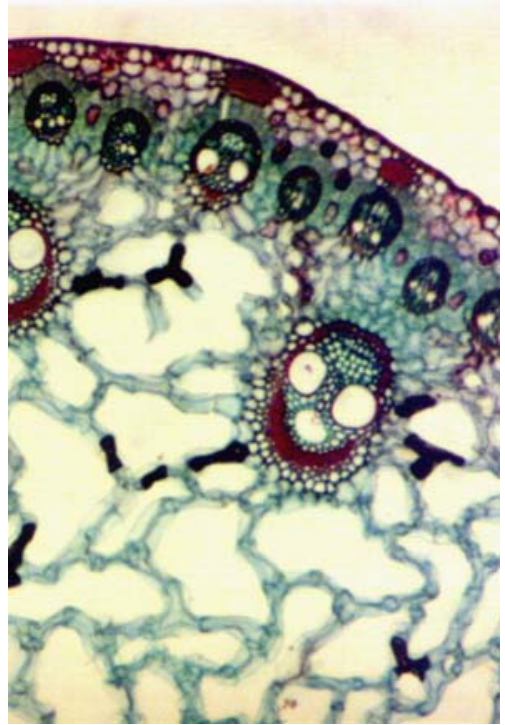

b

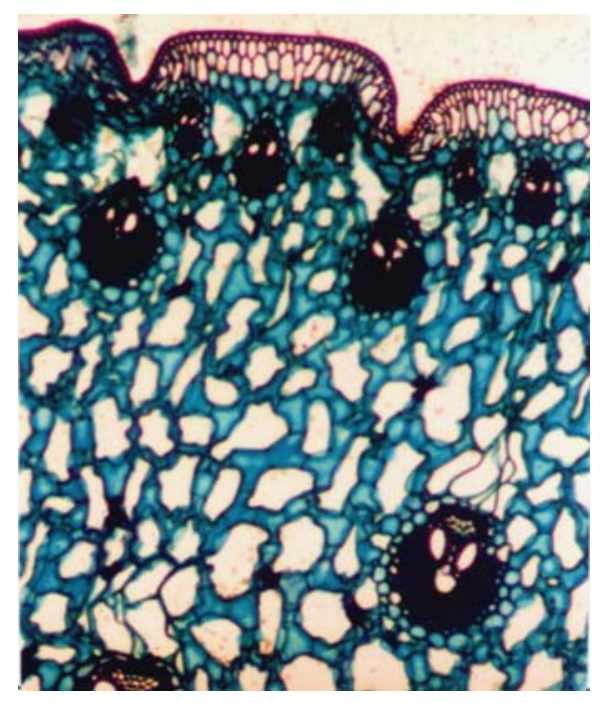

C

Fig. (1): a: T.S. in Cyperus papyrus culm (x 50 ), b: T.S. in Cyperus alopecuroides culm (x 50), c: T.S. in Cyperus articulatus culm (x 50). 
N. M. Waly

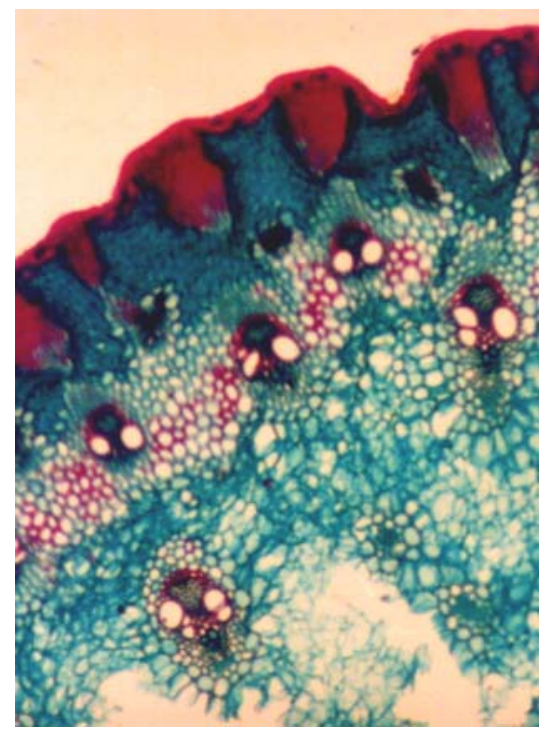

a

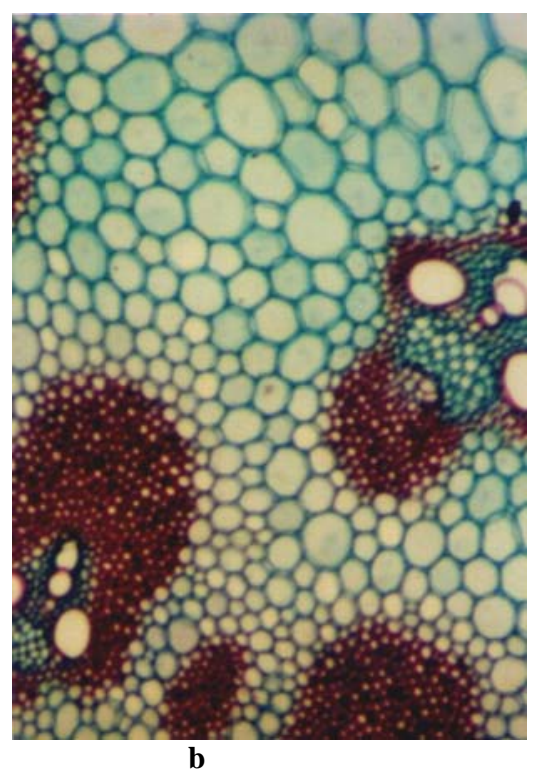

b

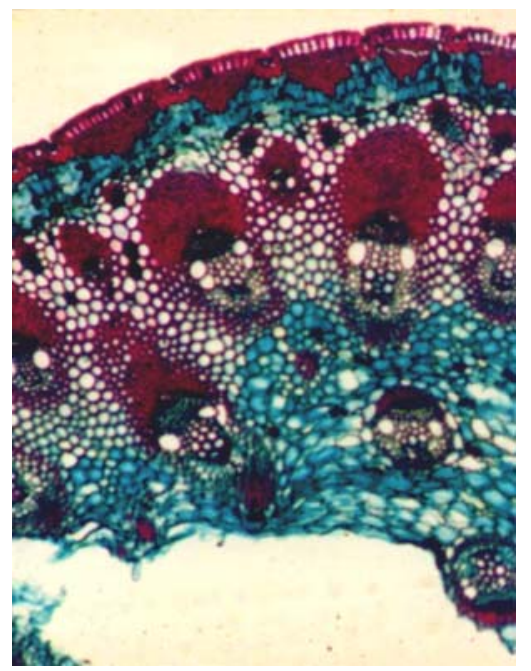

C

Fig. (2): a: T.S. in Juncus rigidus culm showing ground tissue with normal parenchyma (x 50), b: T.S. in Zea mays culm showing ground tissue with normal parenchyma (x50), c: T.S. in Juncuc acutus culm showing ground tissue with normal parenchyma (x50) 
Papyrus and Papyrus - like paper sheets, their quality in relation to anatomical features

\section{Acknowledgments:}

The writer is indebted to Professor M. N. El-Hadidi, for his encouragement, useful comment, and reading through the final draft of this account.

\section{References}

Basile, C. \& Di Natale, 1996. Un contributo alla manifattura dei papiri: esperienze, teorie, and nuove ricerche. In Atti del II Convegno Nazionale di Egittologia e Papirologia, Siracusa, 1-3 Dicembre, 1995.Siracusa: Instituto Internazionale del Papiro-Siracusa

El Hadidi, M.N. 1982. The Predynastic Flora of Hierakonpolis region, in M.A. Hoffman (ed.) The Predynastic of Hierakonpolis- an interim report, Egypt studies. Assoc. 1: 102-115. Cairo University Herbarium and Dept. of Sociology and Anthropology, Illionois-USA.

Lucas, A. 1962. Ancient Egyptian Materials and Industries. $4^{\text {th }}$ ed. Rev. J.R. Harris. London: Edward Arnold.

Metcalfe, C.R. (ed). 1971. Anatomy of the Monocotyledons, V: Cyperaceae-Oxford: Clarendon Press.

Nicholson T. Paul and Ian Shaw, 2000. Ancient Egyptian Materials and Technology. Cambridge - University Press.

Ragab, H. 1980 a. A new theory brought forward about the adhesion of papyrus strips. Institute of Paper Historians: Yearbook, 1980:113-24

------, 1980 b. Le Papyrus. Cairo: Dr. Ragab Papyrus Institute.

-------, 1988. The quality of recent manufactured Papyrus. In Proceedings of the XVIII International Congress of Papyrology, Athens, 25-31.

Täckholm, V and Drar, M. 1950. Flora of Egypt- Bulletin of the Faculty of Science 28. Cairo: Fouad I University Press.

Walker, A. 1988. The use of a facing technique in the treatment of fragile papyri. In conservation of Ancient Egyptian, A. Materials: Preprints (ed., S.C. Watkins and C.E.Brown). Bristol; UKIC Archaeology cession. 